\title{
LXI. Report on the discovery of a deposit of bituminous wood. Read in the Ligurian Institute July 1802
}

\section{Mojon}

To cite this article: C. Mojon (1803) LXI. Report on the discovery of a deposit of bituminous wood. Read in the Ligurian Institute July 1802, Philosophical Magazine Series 1, 16:64, 324-327, DOI: $10.1080 / 14786440308676355$

To link to this article: http://dx.doi.org/10.1080/14786440308676355

曲 Published online: 18 May 2009.

Submit your article to this journal $\pi$

Џll Article views: 2

Q View related articles $\sqsubset$ 
olive oil, and at a fourth of the expense, as the petroleum costs only two Genoese sous per pound, (which is less than a penny English.)

LXI. Report on the Discovery of a Deposit of lituminous Wood. Read in the Ligurian Institute July 1802 by C. Moson, pullic Professor of Chemistry *

$A_{T}$ the period when nature opened in the state of Parma, on the north side of the Appenines, an extraordinary spring of petroleum $\uparrow$, it presented on the opposite side, in Liguria, at the distance of about fitteen leagues, a considerable depôt of bituminous wood. The discovery of this fossil is even a little more recent, and is equally interesting to the naturalist and to the state. For a knowledge of it we are indebted to the useful labours of professor Mojon, as will be seen by the following extract from the report which he made to the National Institute of Liguria:

"Castel Nuovo is a country of Lunigiana on the confines of the Italian republic. It is in the plain of that country, half a league from the mouth of the Magra, that the mine of the substance in question has been discovered. It is situated in a soil formed of argillaceous and calcareous strata, more or less thick, and inclined in different directions throughout their whole extent. The nature of the fossil, as well as the constitution of the soil, evidently shows that these strata were formed only by great floods, which carried with them and buried whole forests $f$. The extent of this deposit, however, cannot be determined, because the pits proposed to be sunk at different distances for that purpose have not yet been constructed. Hitherto one only has been made, about 40 feet in depth, the bottom of which is inundated by a spring that issues from an excavation attempted in a lateral direction; and it is to be observed, that in this pit no disengagement has been remarked of carbonic acid gai, nor of those gases generally developed from such excavations.

* From the Annales de Chimie, No. 135.

+ See the preceding article.

I Is there not reassin to believe that the lucus sacer of the antient Lun must form part of this deposit? The ruins of the towll, in digging among which mouuments worthy the attention of the antiquary have lately been discovered, are found very near, and at the distance of the third of a league from the mouth of the Magra. 
6 This bituminous wood, which in some places appears almost uncovered, at the surface of the ground still retains its primitive figure. In the course of the search which has been made by digging, trunks of different thickness up to two feet diameter have been dug up; and among these there are some compressed, which exhibit in their transverse section an elliptical form.

" The colour of this fossil is sometimes a perfect black, sometimes a grayish black, and somerimes a wood brown. The blackest is sometimes pretty shining, and has even tlee splendour of glass; the grayish black, and brown, are dul!, but shine very much on being polished.

"Its texture is entirely that of wood, as it has not been altered by the bitumen with which it is improsnated; so that in some pieces the tree to which they belonged may be determined: and in particular those which have the transverse fracture conchord and shining, and which are perfectly black, exhibit all the characters of fir : others have a texture similar to that of oak.

"It is not so brittle as coal, and, when sawn in a direction perpendicular to the axis of the trunks, exhibits a solid, compact, and very smooth surface. The concentric strata of the fibres of which the trunk is composed may be easily separated by introducing the point of any instrument whatever.

"It readily kindles, and without the aid of any other combustible: it gives in burning a lively and brilliant flame. The heat it produces is more intense and durable than that of any other vegetable coal ; and, when once kindled, never becomes extinct till entirely consumed, leaving. very little ashes. The combustion may be interrupted and renewed at pleasure.

"Lighter than coal, its specific gravity is to that of distilled water as 1235 to 1000 : the tragments which exhibit the characters of oak are still lighter.

" Sulphuret of iron is sometimes found in this fossil disseminated in lumps and small grains, which when long exposed to the air are decomposed, and cause the fragments to which they belong to fall in pieces.

"It has besides the properties common to coal : but if naturalists have long entertained doubts respecting the origin of coals, in consequence of the variety of their texture, the irrcgularity of their form, their fragility, their strata analogous to those of schistous stones, \&c., the fossil of Castel Nuovo presents no difficulty to their researches. The uniformity of the tissue; the constant direction of its fibres; 
the bark of the different trunks; its knots; fracture; the colour of some kinds; the facility with which it inflames; the alkali contained in its ashes;--all these characters, very distinct, render it perfectly similar to charred wood.

" It must also be added, that it possesses this singular property, that it is susceptible of being worked in the lath with the greatest facility, and of acruiring a polish and splendour which render it superior to ebony.

"In the last place, it is a conductor of the electric fluid, and transmits it with facility."

After this short account of the situation and nature of this fossil, I shall describe some of the experiments which. the author made, in order to determine what advantages may be derined from the employment of this substance.

He burnt 12 pounds of this bituminous wood in a furnace, adapting to it a thermometer at the distance of eight inches, the temperature at the time being 10 degrees of Beaumur. Sixteen minutes after, the whole wood was completely kindled, and gave a clear brilliant flame, with less smoke than coal and a slight odour of bitumen, which not being sulphureous did not incommode those persons even who were nearest to it. The thermometer had risen to 42 degrees. Twenty-four pounds of water, which were in a copper vessel on the furnace, then began to boil. The thermometer stood at the same degree for 12 minutes, and the water continued to boil for 20. When the ebullition had ceased the thermometer fell to 26 degrees, and the water was reduced to three pounds. The fossil was entirely consumed in the course of an hour and a quarter, and left 225 grains of yellowish impalpable ashes in the form of flakes.

He then repeated the experiment under the same circumstances, and with oak chareoal. The latter kindled in twelve minutes, and in four more the 24 pounds of water contained in the copper boiler entered into ebullition. The thermometer rose to 38 degrees, at which it maintained itself for 18 minutes, and when the ebullition ceased the thermometer fell to 25 degrees. Almost the whole of the water was evaporated, and the coal, being consumed in the course of $2 n$ hour and a half, left only 154 grains of ashes.

By this experiment, calculating the sum total of the heat respectively extricated during the combustion of the two substances, the author was able to remark, that the bituminous wood produced 816 degrees of heat during an hour and a quarter; while oak charcoal, in an hour and a half, produced only 784 . 
He also tried whither this fossil could be used with advantage in forges for forging iron. He kept at a red heat for some time the extremities of an iron rod, one in bituminous wood and the oiher in oak charcoal, employing equal parts. When the iron rod was taken out, he found its extremities equally ductile, malleable, and tenacious. There is every reason to think that this new combustible may even be employed in the reduction of iron ore; but this the author has not been able to ascertain, for want of materials.

Professor Mojon terminates his report with the following analysis :

This fossil wood gives almost the same products as coals, if we except the ashes, from which a little potash is extracted.

By distillation he obtained phlegm, yellowish bituminous oil, a quantity of carbonic acid gas, carbonated hydrogen gas, and an empyreumatic oil thicker than the former.

In alcohol a portion of this wood, at the end of some time, gave a blackish resinous substance.

By ebullition in distilled water it suffers to be precipitated calcareous earth and argil.

By pouring nitric acid over this fossil, it is decomposed, disengaging nitrous gas.

In the last place, the 225 grains of ashes, obtained by the above combustion of 12 pounds of this fossil, gave by lixivi-

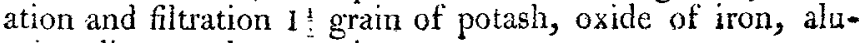
mine, lime, and magnesia.

LXII. Memoir on aëriform cutaneous Perspiration. By C. Trousset, M. D. Professor of Natural Philosophy and Chemistry in the Central School of the Department of Isere, छ̋c.*

$\mathrm{P}$

Perricians at all times have endeavoured to ascertain the influence which the air has on the human body ; but how can we conreive that the antients, who were not acquainted with the gravity of that fluid, should have been able to determine its action? If we therefore except Hippocrates, who formally asserts in his works that air is digested in the lungs as the aliments are in the stomach, his contemporaries and successors have left us on this subject incoherent ideas, often ridiculous, and always erroneous, the fruits of an ima. gindtion not guided by any certain experience. 